\title{
Dry matter yield and radiation use efficiency of four autumn sown top flowering annual clovers
}

\author{
H. NORI ${ }^{1}$, D.J. MOOT ${ }^{2}$ and A.D. BLACK ${ }^{2}$ \\ ${ }^{I}$ Faculty of Resource Science and Technology, University Malaysia Sarawak, Malaysia. \\ ${ }^{2}$ Faculty of Agriculture and Life Sciences, Lincoln University, Canterbury, New Zealand. \\ nhollena@frst.unimas.my
}

\begin{abstract}
Monocultures of arrowleaf (Trifolium vesiculosum), balansa (T. michelianum), gland (T. glanduliferum) and Persian (T. resupinatum) clovers were sown on four dates in autumn and winter 2010. Dry matter (DM) accumulation was dependent on the duration of crop growth which was influenced by the time of sowing. Autumn sown crops which flowered latest had a longer duration of vegetative growth and consequently produced the highest dry matter yields. In the establishment year, autumn sown crops produced up to $17.5 \mathrm{t} \mathrm{DM} / \mathrm{ha}$ for balansa, $12.5 \mathrm{t}$ $\mathrm{DM} /$ ha for Persian, $11.0 \mathrm{t} \mathrm{DM} / \mathrm{ha}$ for gland and 9.4 t $\mathrm{DM} /$ ha for arrowleaf at physiological maturity $(\mathrm{P}<0.05)$. Crops that were sown in winter produced the lowest yield, because reproductive development commenced earlier and therefore they matured earlier. 'Bolta' balansa clover had the highest radiation use efficiency of $2.1 \mathrm{~g} \mathrm{DM} / \mathrm{MJ}$ photosynthetically active radiation (PAR) absorbed followed by gland $(1.6 \mathrm{~g}$ DM/MJ PAR), arrowleaf and Persian (1.3 g DM/MJ PAR) clovers. In the second year, regenerated dry matter production at full flower was up to $11.6 \mathrm{t} / \mathrm{ha}$ in balansa, $8.3 \mathrm{t} / \mathrm{ha}$ in Persian, $2.9 \mathrm{t} / \mathrm{ha}$ in gland but only $0.5 \mathrm{t} / \mathrm{ha}$ in arrowleaf clover $(\mathrm{P}<0.05)$. Thus, over the two years 'Bolta' balansa and 'Mihi' Persian clovers were the highest yielding and easiest to regenerate from seed in monocultures. 'Cefalu' arrowleaf failed to regenerate in the second year due to low population of seedling emergence. 'Prima' gland clover was low yielding because it flowered and matured without fully utilising the growing season.
\end{abstract}

Keywords: biomass, canopy expansion, day length, light interception, thermal time.

\section{Introduction}

Annual clovers can be used as cool season forages due to their faster growth in cool weather than perennial clovers. They have high nutritive value, with $18-25 \%$ crude protein and $60-80 \%$ dry matter digestibility (Allinson et al. 1985; Knight \& Watson 1977 ). Sheep tend to selectively graze clover in preference to grass and prefer a diet of 50-70\% clover (Cosgrove et al. 1999; Hyslop et al. 2003). Top flowering annual clovers such as arrowleaf (Trifolium vesiculosum), balansa (T.michelianum), gland (T.glanduliferum) and Persian clover (T. resupinatum) have been introduced into New Zealand dryland regions to increase the diversity of pasture components in mixed swards. However, these species are currently not widely used. They may have potential to be included as monocultures or as part of pasture mixes in summer dry environments. To date, there are little comparative data available on their growth and ability to regenerate from seed.

The timing of peak growth and maturity of annual clovers are species dependent but may be modified by the date of sowing or opening rains when pastures regenerate in subsequent years. The growth of plants involves energy conversion where incident light is transformed into biomass through photosynthesis. Under optimum growth conditions, the maximum yield of a crop is dependent on the availability and amount of photosynthetically active radiation (PAR) intercepted by the leaf canopy (Cooper 1970; Loomis et al. 1971; Monteith 1972). Specifically, the accumulation of crop dry matter production is proportional to the accumulation of intercepted PAR (Kiniry et al. 1989). The slope of this fitted relationship represents the radiation or light use efficiency (Sinclair \& Muchow 1999).

In annual crops, the accumulation of dry matter is affected by the duration of vegetative growth which is controlled by the time of flowering (Monks et al. 2008). Later flowering crops have prolonged vegetative growth and therefore are expected to produce more dry matter than early flowering crops. Nevertheless, the time of flowering in annual clovers is dependent on the date when the seeds are sown (Monks et al. 2010; Nori et al. 2014). In addition, the survival of annual species is determined by the ability of seeds to regenerate populations in the following season.

In this paper, the objectives were (1) to quantify dry matter production from four annual clovers sown on four dates, (2) to explain any yield differences in relation to light interception and radiation use efficiency and then (3) to assess the regeneration of crop biomass after the first year. An understanding of the growth of these species is then used to discuss their potential in a New Zealand environment. 


\section{Materials and methods}

\section{Experimental site and design}

The experimental area was located in Iversen field at Lincoln University, Canterbury, New Zealand $\left(43^{\circ}\right.$ $38^{\prime} \mathrm{S}, 172^{\circ} 28^{\prime} \mathrm{E}, 11 \mathrm{~m}$ a.s.1.). The soil is classified as Wakanui silt loam with $1.8-3.5 \mathrm{~m}$ of fine textured material overlying gravels (Cox 1978). Mean annual rainfall was $600 \mathrm{~mm}$ in 2010-2012. The mean daily air temperature followed a similar pattern in each season, ranging from $6-8^{\circ} \mathrm{C}$ in June-August to $16-20^{\circ} \mathrm{C}$ in February. This field experiment was established as a split-plot within a randomised complete block design. The main-plots were four sowing dates (26 February, 24 March, 19 April and 8 July 2010) with four replicates. The subplots were pure stands of 'Cefalu' arrowleaf $(6 \mathrm{~kg} / \mathrm{ha})$, 'Bolta' balansa $(4 \mathrm{~kg} / \mathrm{ha})$, 'Prima' gland $(4 \mathrm{~kg} / \mathrm{ha})$ and 'Mihi' Persian clover (5 kg/ha). These species were sown at different rates based on final germination test and seed weight data. The aim was to target seedling emergence at ca. 400 seedlings/ $\mathrm{m}^{2}$. Each subplot measured $4.2 \times 10 \mathrm{~m}$ drilled into a cultivated seedbed with an Øyjoord cone seeder, at 150 $\mathrm{mm}$ row spacing. All seeds were sown with Group C inoculant (ALOSCA Tech. Pty. Ltd. Australia).

\section{Management}

Plots sown on 26 February 2010 were sprayed on 3 June 2010 with a mixture of Preside (a.i. $800 \mathrm{~g} / \mathrm{kg}$ flumetsulam) at $65 \mathrm{~g} / \mathrm{ha}$ and 'Hasten' wetting agent at 2 litres/ha to control broad leaf weeds, particularly fathen (Chenopodium album). On 17 June 2010, Centurion Plus (a.i. $125 \mathrm{~g} /$ litre clethodim) was applied at 1 litre/ ha to plots sown on 26 February 2010 and 24 March
2010 to control grass weeds. No irrigation was applied and plots were not grazed throughout the experimental period to compare maximum production and seed set. When all the seed pods had shattered, the dead herbage was removed on 29 April 2011, using a rotary mower to facilitate seedling establishment. All plots were sprayed on 1 August 2011 with Gallant Ultra (a.i. 520 g/litre haloxyfop-P) at $250 \mathrm{ml} / \mathrm{ha}$ to control grass weeds. The experimental area remained ungrazed and clover seedlings were left to grow to flowering for the second season to assess regeneration potential.

\section{Measurements}

For each sowing date, air temperatures were monitored from seedling emergence to full flower through a sensor placed at the experiment site. Temperatures were recorded every hour with a HOBO data logger to determine daily maximum and minimum temperatures for thermal time calculation (Nori et al. 2014). For each sowing date, air temperatures were monitored from seedling emergence to full flower from a sensor placed at the experiment site.

Plant populations were counted at the appearance of the first trifoliate leaf. Dry matter (DM) was measured bi-monthly during winter and bi-weekly during spring and summer. Measurements started when the crop height reached ca. $70 \mathrm{~mm}$ and ended at crop physiological maturity. Herbage was cut from a $0.2 \mathrm{~m}^{2}$ quadrat at $30 \mathrm{~mm}$ above ground. For regeneration in the second year, the DM was measured once, at full flower for each clover species. Full flower or peak flowering was defined when $\geq 50 \%$ of the plant population within a plot had fully open flowers. The herbage sub-samples

Table 1 Plant population $/ \mathrm{m}^{2}$ and their percentage (\%, in brackets) of 'Cefalu' arrowleaf, 'Bolta' balansa, 'Prima' gland and 'Mihi' Persian clovers sown on four dates in 2010 at Iversen 9 field, Lincoln University, New Zealand.

\begin{tabular}{|c|c|c|c|c|}
\hline \multirow{2}{*}{$\begin{array}{l}\text { Sowing date } \\
\text { (SD) }\end{array}$} & \multicolumn{4}{|c|}{ Plant population $/ \mathrm{m}^{2}$ and their percentage (\%, in brackets) } \\
\hline & ‘Cefalu’ arrowleaf & 'Bolta' balansa & 'Prima' gland & 'Mihi’ Persian \\
\hline 26 Feb & $236(31.9)$ & $283(59.9)$ & $375(48.3)$ & $133(39.6)$ \\
\hline $24 \mathrm{Mar}$ & $125(16.9)$ & $144(30.5)$ & $173(22.2)$ & $75(22.4)$ \\
\hline $19 \mathrm{Apr}$ & $178(24.0)$ & $235(49.7)$ & $393(50.6)$ & $117(34.9)$ \\
\hline \multirow[t]{2}{*}{$8 \mathrm{Jul}$} & $172(23.2)$ & $142(30.0)$ & $317(40.8)$ & $149(44.6)$ \\
\hline & & SD & Species & SD*Species \\
\hline \multicolumn{2}{|l|}{ P-value } & $<0.002$ & $<0.001$ & $<0.004$ \\
\hline \multicolumn{2}{|l|}{ V.r. } & 12.4 & 48.5 & 3.4 \\
\hline \multicolumn{2}{|l|}{ S.E.M. } & 15.7 & 11.8 & 25.8 \\
\hline \multicolumn{4}{|c|}{ Except when comparing means at the same SD } & 23.6 \\
\hline \multicolumn{2}{|l|}{ L.S.D. (5\%) } & 50.2 & 33.8 & 73.7 \\
\hline \multicolumn{4}{|c|}{ Except when comparing means at the same SD } & 67.6 \\
\hline
\end{tabular}

V.r. Variance ratio; S.E.M. Standard error of the mean; L.S.D. Least significant differences. 
were sorted into clover and weeds before dry weight determination.

Canopy light interception was measured at 14-21 day intervals using a SunScan Canopy Analysis System (Delta-T Devices, Cambridge, England), starting from when the canopy reached a height of ca. $70 \mathrm{~mm}$. The leaf area index is not reported because no independent data set was measured to validate the Sunscan's calculation and the main measurement required was light interception. Dry matter accumulation in relation to thermal time was described using a logistic growth function (Loss et al. 1989). The fraction of intercepted PAR $(\tau)$ was calculated from the differences between the incident and transmitted PAR (Gallagher \& Biscoe

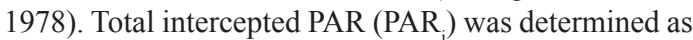
the sum of daily PAR from emergence to the final date of crop harvest. The canopy expansion was described by the increment amount of intercepted PAR over time. To determine the duration $\left({ }^{\circ} \mathrm{C}\right.$ days) to reach $95 \%$ of total intercepted PAR, a logistic function (Loss et al. 1989) was fitted from the relationship between fraction of intercepted PAR $(\tau)$ and thermal time accumulation.

Absorbed PAR was assumed to be equal to 0.85 of total PAR $_{\mathrm{i}}$ (Sinclair \& Muchow 1999). Radiation use efficiency (RUE) was calculated as the slope of a fitted linear relationship between DM accumulation and total absorbed PAR (Sinclair \& Muchow 1999). For this calculation, the DM accumulation includes weeds because the measurement of light interception was conducted in the field plots where some treatments had weeds present.

\section{Results}

\section{Plant population}

The number of seedlings $/ \mathrm{m}^{2}$ was affected by the sowing date $\times$ species interaction $(\mathrm{P}<0.004)$. with the lowest plant population (17-31\%) from seeds sown on 24 March 2010. In most cases, emergence from March sowing appeared to be affected by a week of low moisture following sowing which delayed emergence.

Table 2 Percentage of weeds (\%) at full flower of 'Cefalu' arrowleaf, 'Bolta' balansa, 'Prima' gland and 'Mihi' Persian clovers monocultures sown on four dates in 2010 (Year 1) at Iversen 9 field, Lincoln University, New Zealand.

\begin{tabular}{lcccc}
\hline Sowing date & \multicolumn{4}{c}{ Percentage of weeds (\%) } \\
\cline { 2 - 5 } (SD) & $\begin{array}{c}\text { 'Cefalu' } \\
\text { arrowleaf }\end{array}$ & $\begin{array}{c}\text { 'Bolta' } \\
\text { balansa }\end{array}$ & $\begin{array}{c}\text { 'Prima' } \\
\text { gland }\end{array}$ & $\begin{array}{c}\text { 'Mihi' } \\
\text { Persian }\end{array}$ \\
\hline 26 Feb 10 & 2 & 3 & 7 & 1 \\
24 Mar 10 & 35 & 10 & 22 & 10 \\
19 Apr 10 & 28 & 6 & 7 & 8 \\
8 Jul 10 & 44 & 37 & 32 & 20 \\
\hline
\end{tabular}

The seedling emergence constituted about $17-32 \%$ ('Cefalu' arrowleaf), 30-60\% ('Bolta' balansa), 22$51 \%$ ('Prima' gland) and 22-45\% ('Mihi' Persian) of the number of seeds sown (Table 1).

\section{Dry matter accumulation}

Crops sown on 26 February 2010 produced the highest dry matter yield of $17.5 \mathrm{t} / \mathrm{ha}$ for 'Bolta' balansa, $12.5 \mathrm{t} / \mathrm{ha}$ for 'Mihi' Persian and $9.4 \mathrm{t} / \mathrm{ha}$ for 'Cefalu' arrowleaf clover (Figure 1). For 'Prima' gland clover, the maximum dry matter production of $11.0 \mathrm{t} / \mathrm{ha}$ was obtained from crops sown on 19 April 2010. In Year 2 the regenerated dry matter production at full flower averaged $11.6 \mathrm{t} / \mathrm{ha}$ for 'Bolta' balansa, $8.3 \mathrm{t} / \mathrm{ha}$ for 'Mihi' Persian and $0.5 \mathrm{t} / \mathrm{ha}$ for 'Cefalu' arrowleaf clover across all sowing dates. For 'Prima' gland clover, the regenerated dry matter production ranged from 1.6 to $2.9 \mathrm{t} /$ ha (Figure 1). The percentage of weeds in these regenerated crops at full flower is shown in Table 2.

'Cefalu' arrowleaf clover reached its peak flowering in November and matured in December. 'Bolta' balansa and 'Prima' gland clovers blossomed in mid-spring and shed seeds before summer. 'Mihi' Persian clover had full flower in December and matured in January. The duration to accumulate $95 \%$ total yield differed $(\mathrm{P}<0.001)$ with sowing date and species. In all species, the duration was shortened with successive sowing dates from $2765^{\circ} \mathrm{C}$ days when sown on 26 February to $1640^{\circ} \mathrm{C}$ days for 8 July sown 'Cefalu' arrowleaf clover (Figure 1a). In comparison among species, 'Prima' gland clover had the shortest duration of biomass accumulation $\left(1070-2100^{\circ} \mathrm{C}\right.$ days). In contrast, 'Mihi' Persian clover had the longest duration $\left(1790-2965^{\circ} \mathrm{C}\right.$ days) of dry matter accumulation. Similarly, the duration of the lag phase or time $\left({ }^{\circ} \mathrm{C}\right.$ days $)$ to accumulate $5 \%$ of total crop dry matter exhibited $(\mathrm{P}<0.001)$ a sowing date $\times$ species interaction (Table 3$)$. In 'Cefalu' arrowleaf, 'Bolta' balansa and 'Prima' gland clovers, crops sown in late February had the longest lag phase duration whereas July sown crops accumulated $5 \%$ of their total dry matter within the shortest time. For 'Mihi' Persian clover, the lag phase averaged $1195^{\circ} \mathrm{C}$ days across all four sowing dates.

\section{Canopy expansion and total intercepted PAR}

In 'Cefalu' arrowleaf clover, only February sown crops managed to intercept $95 \%$ PAR after $2224^{\circ} \mathrm{C}$ days whereas the other three sowing dates did not reach $95 \%$ $\mathrm{PAR}_{\mathrm{i}}$ before maturity. For the other three species, the duration from seedling emergence to $95 \% \mathrm{PAR}_{\mathrm{i}}$ ranged from 1553 to $1728^{\circ} \mathrm{C}$ days in 'Bolta' balansa, 1484 to $1979^{\circ} \mathrm{C}$ days in 'Prima' gland and was ca. $2007^{\circ} \mathrm{C}$ days in 'Mihi' Persian clover. In all species, July sown crops matured before their canopy was completely closed. There was an interaction $(\mathrm{P}<0.001)$ between the sowing date and species in the total intercepted PAR. 


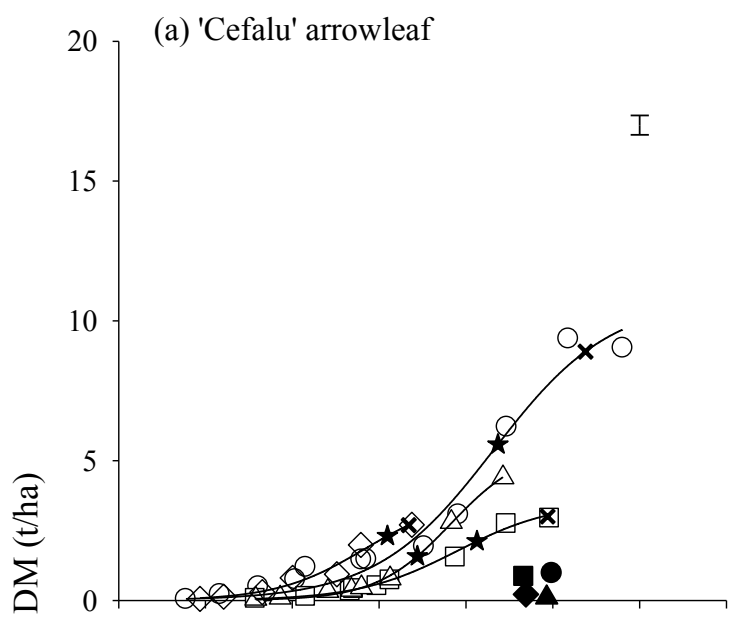

(c) 'Prima' gland

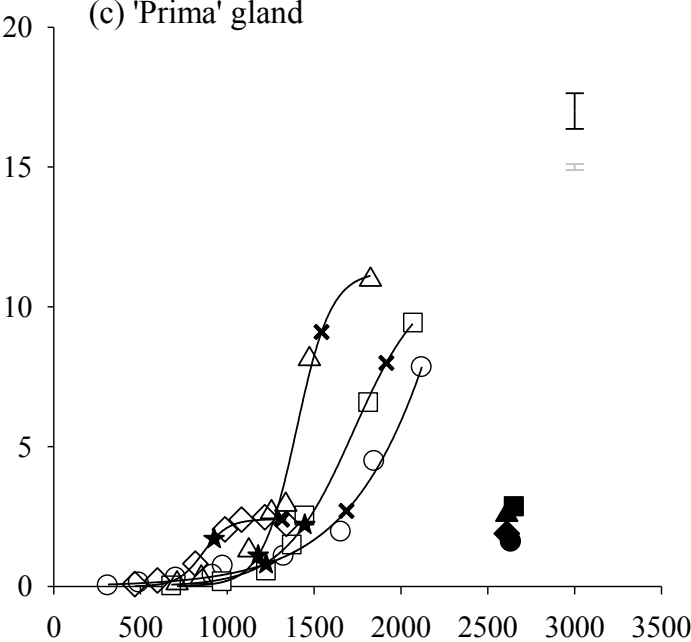

(b) 'Bolta' balansa

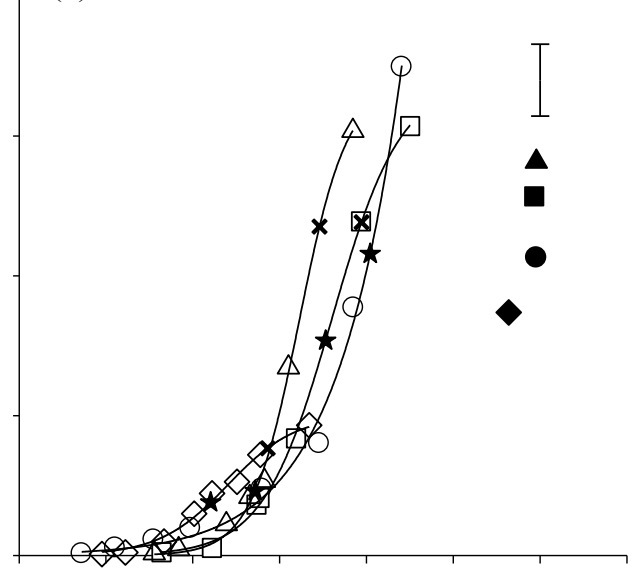

(d) 'Mihi' Persian

Accummulated thermal time $\left({ }^{\circ} \mathrm{C}\right.$ days $)$ after emergence

Figure 1 Accumulated legume dry matter plus seeds (t/ha) of (a) 'Cefalu' arrowleaf, (b) 'Bolta' balansa, (c) 'Prima' gland and (d) 'Mihi' Persian clovers sown on four dates at Lincoln University, Canterbury, New Zealand. Sowing date: 26 Feb 10 (O, ๑), 24 Mar $10(\square, \boldsymbol{D}), 19$ Apr $10(\triangle, \mathbf{\Delta}), 8$ Jul $10 \diamond, \diamond)$. Full flower $(\star)$, Physiological maturity $(\mathrm{X})$. Closed symbols are the dry matter at full flower from the regenerated annual clovers in year two (2011). Bars represent one standard error of the mean where sowing dates were different $(\mathrm{P}<0.05)$; for (c) 'Prima' gland clover,lower bar represents regenerated clover in year two (2011). Note:Thermal time calculation used air temperature $\left(\mathrm{T}_{\mathrm{b}}=0^{\circ} \mathrm{C}\right)$.

In 'Cefalu' arrowleaf clover, total $\mathrm{PAR}_{\mathrm{i}}$ decreased with successive sowing dates from $880 \mathrm{MJ} / \mathrm{m}^{2}$ in February to $484 \mathrm{MJ} / \mathrm{m}^{2}$ in July (Table 4). 'Bolta' balansa clover sown in March intercepted the highest PAR of $875 \mathrm{MJ} /$ $\mathrm{m}^{2}$. For 'Prima' gland clover, crops sown in March and April both intercepted ca. 814 MJ PAR $/ \mathrm{m}^{2}$. 'Mihi' Persian clover had the lowest PAR intercepted (641 $\mathrm{MJ} / \mathrm{m}^{2}$ ) by crops sown in July.

\section{Radiation use efficiency (RUE)}

At full flower, the highest crop yield for each species was $6.3 \mathrm{t}$ /ha for 'Cefalu' arrowleaf (26 February), ca.1590 g DM/m² (19 April) or $15.9 \mathrm{t} / \mathrm{ha}$ for 'Bolta' balansa, ca. $810 \mathrm{~g} \mathrm{DM} / \mathrm{m}^{2}$ (19 April) or $8.1 \mathrm{t} / \mathrm{ha}$ for 'Prima' gland and ca. $1220 \mathrm{~g} \mathrm{DM} / \mathrm{m}^{2}$ (19 April) or 12.2 t/ha for 'Mihi' Persian clover (Figure 2). These yields required the absorption of PAR of ca. $470 \mathrm{MJ} / \mathrm{m}^{2}$ in 'Cefalu' arrowleaf, ca. $670 \mathrm{MJ} / \mathrm{m}^{2}$ in 'Bolta' balansa, ca. $390 \mathrm{MJ} / \mathrm{m}^{2}$ in 'Prima' gland and ca. $750 \mathrm{MJ} / \mathrm{m}^{2}$ in 'Mihi' Persian clover. Therefore, the RUE was $1.3 \mathrm{~g}$ DM/MJ PAR for 'Cefalu' arrowleaf, $2.1 \mathrm{~g} \mathrm{DM} / \mathrm{MJ}$ PAR for 'Bolta' balansa, 1.6 g DM/MJ PAR for 'Prima' gland and $1.3 \mathrm{~g} \mathrm{DM}$ /MJ PAR for 'Mihi' Persian clover (Table 5). These values of RUE equates to PAR utilisation of 
$2.3 \%$ for arrowleaf, $3.7 \%$ for balansa, $2.8 \%$ for gland and $2.3 \%$ of Persian clover based on the assumption that $1 \mathrm{~g}$ of carbohydrate plant dry matter yields $17.5 \mathrm{~kJ}$ of energy combustion (Monteith 1977).

Table 3 Duration of lag phase $\left({ }^{\circ} \mathrm{C}\right.$ days) of dry matter accumulation for 'Cefalu' arrowleaf, 'Bolta' balansa, 'Prima' gland and 'Mihi' Persian clovers sown on four dates in 2010 at Iversen 9 field, Lincoln University, New Zealand.

\begin{tabular}{lcccc}
\hline Sowing date & \multicolumn{4}{c}{$\begin{array}{c}\text { Duration of lag phase }\left({ }^{\circ} \mathrm{C} \text { d) }\right. \\
\text { of dry matter accumulation }\end{array}$} \\
\cline { 2 - 5 } (SD) & $\begin{array}{c}\text { 'Cefalu' } \\
\text { arrowleaf }\end{array}$ & $\begin{array}{c}\text { 'Bolta' } \\
\text { balansa }\end{array}$ & $\begin{array}{r}\text { 'Prima' } \\
\text { gland }\end{array}$ & $\begin{array}{c}\text { 'Mihi' } \\
\text { Persian }\end{array}$ \\
\hline 26 Feb & 1433 & 1382 & 1267 & 981 \\
24 Mar & 1155 & 1323 & 1168 & 1213 \\
19 Apr & 1356 & 1284 & 1141 & 1326 \\
8 Jul & 822 & 758 & 580 & 1114 \\
\hline & SD & Species & SD*Species \\
\hline P- value & $<0.001$ & $<0.041$ & $<0.001$ \\
V.r. & 45.8 & & 3.1 & 4.2 \\
S.E.M. & 32.3 & & 40.9 & 77.8 \\
Except when comparing means at the same SD & 81.7 \\
L.S.D. (5\%) & 103.4 & \multicolumn{2}{c}{117.2} & 221.6 \\
Except when comparing means at the same SD & 234.4 \\
\hline
\end{tabular}

V.r. variance ratio; S.E.M. Standard error of the mean;

L.S.D. Least significant differences at 0.05 .

Table 4 Total intercepted PAR (PARi) by 'Cefalu' arrowleaf, 'Bolta' balansa, 'Prima' gland and 'Mihi' Persian clovers sown on four dates in 2010 at Iversen 9 field, Lincoln University, New Zealand.

\begin{tabular}{|c|c|c|c|c|}
\hline \multirow{2}{*}{$\begin{array}{l}\text { Sowing date } \\
\text { (SD) }\end{array}$} & \multicolumn{4}{|c|}{ Total PAR $\left(M J / m^{2}\right)$} \\
\hline & $\begin{array}{l}\text { ‘Cefalu' } \\
\text { arrowleaf }\end{array}$ & $\begin{array}{l}\text { 'Bolta' } \\
\text { balansa }\end{array}$ & $\begin{array}{l}\text { 'Prima' } \\
\text { gland }\end{array}$ & $\begin{array}{c}\text { 'Mihi' } \\
\text { Persian }\end{array}$ \\
\hline 26 Feb & 880 & 690 & 543 & 1006 \\
\hline 24 Mar & 655 & 875 & 838 & 972 \\
\hline $19 \mathrm{Apr}$ & 614 & 787 & 789 & 1172 \\
\hline \multirow[t]{2}{*}{$8 \mathrm{Jul}$} & 484 & 786 & 542 & 641 \\
\hline & SD & \multicolumn{2}{|c|}{ Species } & SD*Species \\
\hline P-value & $<0.001$ & \multicolumn{2}{|c|}{$<0.001$} & $<0.001$ \\
\hline V.r. & 14.6 & \multicolumn{2}{|c|}{62.3} & 18.3 \\
\hline S.E.M. & 27.8 & \multicolumn{2}{|c|}{16.8} & 40.3 \\
\hline \multicolumn{4}{|c|}{ Except when comparing means at the same SD } & 33.6 \\
\hline L.S.D. (5\%) & 89 & \multicolumn{2}{|c|}{48.2} & 116.2 \\
\hline \multicolumn{4}{|c|}{ Except when comparing means at the same SD } & 96.4 \\
\hline
\end{tabular}

V.r. Variance ratio; S.E.M. Standard error of the mean; L.S.D. Least significant differences.

\section{Discussion}

The amount of seed sown in 2010 was sufficient to produce pure swards of these legumes that then enabled them to grow to their potential from the different sowing dates in the establishment year. A comparison of their vegetative yield, time of feed production and ability to regenerate from seed allows inferences to be made of their potential for integration into New Zealand farming systems. The most successful species appeared to be 'Bolta' balansa clover. It was the highest yielding species and produced over $15 \mathrm{t} \mathrm{DM} /$ ha (Figure 1) from the three autumn sowing dates (26 February-19 April). These autumn dates are consistent with autumn sowing practices in dryland east coast regions of New Zealand. Sowing in autumn allows the clovers to set seeds and complete their life cycle in summer. These annuals then regenerate from seeds following autumn rain in the next season. Indeed the second year yields of balansa clover at full flower were equivalent to those produced in the establishment season. The exception was the 8 July sown crop which produced less than 5 $\mathrm{t} \mathrm{DM} / \mathrm{ha}$ in the establishment year but over $8 \mathrm{t} \mathrm{DM} /$ ha in the regeneration year. These results show balansa

Table 5 Radiation use efficiency (g DM/MJ PAR absorbed) from fitted regression between crop dry matter to full flower $\left(\mathrm{g} / \mathrm{m}^{2}\right)$ and total PAR absorbed $\left(\mathrm{MJ} / \mathrm{m}^{2}\right)$ of 'Cefalu' arrowleaf, 'Bolta' balansa, 'Prima' gland and 'Mihi' Persian clover sown on four dates in 2010 at Lincoln University, New Zealand.

\begin{tabular}{|c|c|c|c|}
\hline Species & $\begin{array}{l}\text { Sowing date } \\
(2010)\end{array}$ & $\begin{array}{c}\text { Radiation use } \\
\text { efficiency } \pm \text { S.E. } \\
\text { (g DM/MJ PAR } \\
\text { absorbed) }\end{array}$ & $\begin{array}{l}R^{2} \\
(\%)\end{array}$ \\
\hline \multirow[t]{4}{*}{ 'Cefalu' arrowleaf } & 26 Feb & $1.26 \pm 0.052$ & 98 \\
\hline & 24 Mar & $1.00 \pm 0.037$ & 99 \\
\hline & $19 \mathrm{Apr}$ & $1.06 \pm 0.088$ & 94 \\
\hline & $8 \mathrm{Jul}$ & $0.97 \pm 0.091$ & 91 \\
\hline \multirow[t]{4}{*}{ 'Bolta' balansa } & 26 Feb & $2.13 \pm 0.146$ & 95 \\
\hline & $24 \mathrm{Mar}$ & $2.54 \pm 0.114$ & 99 \\
\hline & $19 \mathrm{Apr}$ & $2.08 \pm 0.221$ & 91 \\
\hline & $8 \mathrm{Jul}$ & $0.97 \pm 0.072$ & 93 \\
\hline \multirow[t]{4}{*}{ 'Prima' gland } & 26 Feb & $1.39 \pm 0.062$ & 98 \\
\hline & $24 \mathrm{Mar}$ & $1.32 \pm 0.125$ & 94 \\
\hline & $19 \mathrm{Apr}$ & $1.61 \pm 0.257$ & 82 \\
\hline & $8 \mathrm{Jul}$ & $1.04 \pm 0.090$ & 93 \\
\hline \multirow[t]{4}{*}{ 'Mihi' Persian } & 26 Feb & $1.23 \pm 0.069$ & 94 \\
\hline & $24 \mathrm{Mar}$ & $1.46 \pm 0.036$ & 99 \\
\hline & $19 \mathrm{Apr}$ & $1.33 \pm 0.126$ & 90 \\
\hline & $8 \mathrm{Jul}$ & $0.96 \pm 0.123$ & 86 \\
\hline
\end{tabular}

$S D$, sowing date. S.E., standard error. $\mathrm{R}^{2}$, coefficient of determination. 

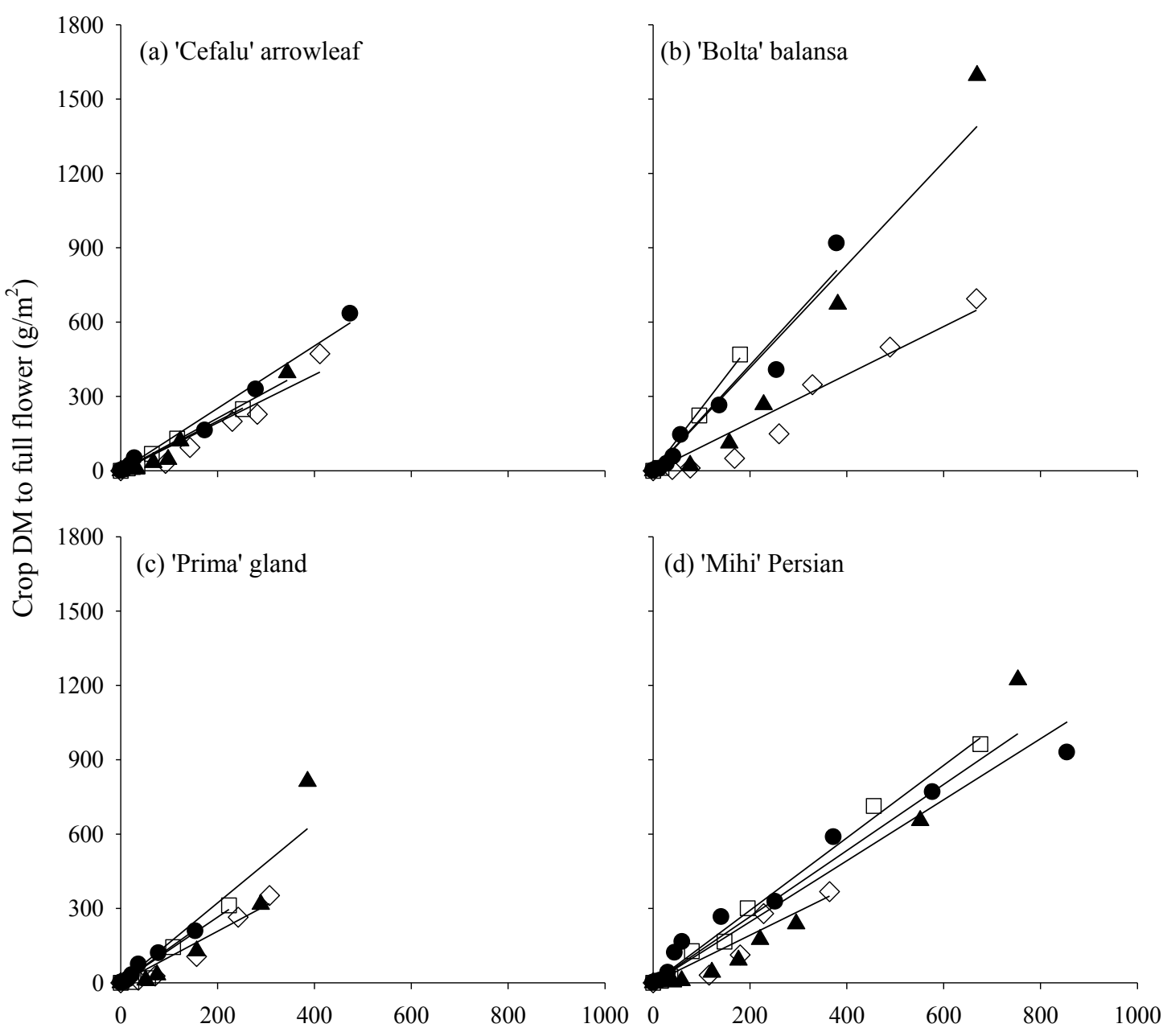

Total PAR absorbed $\left(\mathrm{MJ} / \mathrm{m}^{2}\right)$

Figure 2 Radiation use efficiency (g DM/MJ PAR absorbed) of (a) 'Cefalu' arrowleaf, (b) 'Bolta' balansa, (c) 'Prima' gland and (d) 'Mihi' Persian clovers sown on four dates at Lincoln University, Canterbury, New Zealand. Sowing date: 26 Feb $10(\bullet)$, 24 Mar $10(\square), 19$ Apr $10(\mathbf{\Delta}), 8$ Jul $10(\diamond)$.

clover was successfully established and regenerated from a wide range of initial sowing dates.

The amount of radiation intercepted by balansa was not different from the other species across sowing dates (Table 4). This implies its yield advantage resulted from a higher radiation use efficiency. The RUE for July sown 'Bolta' balansa clover, which had 37\% weeds was $0.97 \mathrm{~g} \mathrm{DM} / \mathrm{MJ}$ PAR compared with $2.13 \mathrm{~g} \mathrm{DM} /$ MJ PAR in February crops which only had $2 \%$ weeds (Table 5). Therefore, the best estimate of RUE is from February sown plots based on the lowest percentage of weeds (1-7\%) (Table 2). Winter annual species are expected to be adapted to cooler temperatures than other perennial and summer grown legumes which have maximum photosynthesis at around $20^{\circ} \mathrm{C}$. In a controlled environment, Nori (2013) found that 'Bolta' balansa clover produced the highest rate of shoot growth at constant temperatures of 11.0 and $15.6^{\circ} \mathrm{C}$, which whould be a useful trait in cool temperate environments. Confirmation requires measurement of photosynthesis rates during periods of low temperature in the winter.

The regeneration of the balansa crop from shed seed highlighted the ease and prolific nature of seeding from these monocultures. High rates of on-farm seed production could enable successful oversowing of balansa into summer dry regions. The ability of balansa clover to survive water logged conditions (Evans \& Snowball 1993) suggests its use in summer dry, winter wet regions of the North Island. Previous work has indicated balansa clover can be used successfully in a grazed situation with cocksfoot (Monks et al. 2008). 
However the loss of legume over time (Mills et al. 2014) highlights the need for specialist management. It may be an easier option to produce specialist monocultures to meet on-farm requirements for spring grazing followed by closing for seed production and regeneration the following year. A non-competitive companion species such as plantain or chicory is suggested to reduce weed invasion and offer production during wet summers.

Maintaining monocultures of all four of these annual clovers did require some weed control. These species all had lag phases of over $1100^{\circ} \mathrm{C}$ days, which indicates a slow initial canopy development post emergence. During this period herbicides were required to control grass and broad leaf weeds for the February and March sowing dates. In a commercial context these may have been controlled by grazing, but this would have confounded the experiment. For the July sowing $20-44 \%$ of the ground cover was weeds and therefore such a late sowing would never be recommended. Should monocultures be desirable for grazing or seed crops then there is a need for specific herbicide recommendations to be developed.

The highest weed content was found in 'Cefalu' arrowleaf clover and it appears to have been the least competitive species at establishment. It had the longest duration of lag phase from the February and March sowing dates. The consequent high weed content contributed to the earlier canopy closure reported for the April and July sowing dates. When the legume content was separated from the weeds the yields of arrowleaf clover were less than $5 \mathrm{tDM} /$ ha except for the February sown crop. The lack of winter and early spring activity in Canterbury supports the conclusion (Evans \& Mills 2008) that arrowleaf is more likely to be useful in areas with warmer winter conditions than at Lincoln. For 'Cefalu' arrowleaf clover, the radiation use efficiency (RUE) for all crops was lower than the other species for March and April (ca. 1.0 g DM/MJ PAR) sown crops (Table 5). It seems most likely that low temperatures experienced during this experiment $\left(4.3^{\circ} \mathrm{C}\right.$ in July to $15.0^{\circ} \mathrm{C}$ in September) restricted photosynthesis rates more in this species than the others tested (Figure 2).

The lack of regeneration of arrowleaf clover in year two highlights the hardseedness of this species (Nori 2013). Previous work in Australia has shown almost $100 \%$ hard seed with arrowleaf being sown to accumulate nitrogen followed by a wheat crop to use the nitrogen before regeneration of the seed in the second year (Loi et al. 2005). Alternatively, heavy grazing during summer to open the sward (Craig \& Ballard 2000) and increase temperature fluctuations near the soil surface to breakdown hard seeds (Quinlivan 1965) have been shown successful in Australia. This remains to be tested in New Zealand. Based on these, and current results, arrowleaf appears to have less potential as an early spring species to meet lactation demands than the other aerial flowering annual clovers tested or the more common subterranean clover (Costello \& Costello 2003). Arrowleaf could potentially be used post-weaning as a specialist crop for high quality feed when grass based pastures are generally going to seed.

'Prima' gland and 'Mihi' Persian clovers were also managed successfully for 2 years with ongoing regeneration expected in subsequent years. However, early flowering limited yield in 'Prima' gland clover. February to April sown crops produced lower yields than balansa and Persian clovers because they grew more slowly during winter. This was reflected in the lower radiation use efficiency compared with balansa clover. Gland clover crops were also the earliest to flower (Figure 1; Nori et al. 2014) and mature seed was produced while other species were still in full flower. Gland clover did not maximise the potential spring growing season and matured too early to take advantage of all of the available soil moisture before the summer dry. Evaluation in areas with a shorter spring duration (lower rainfall) than that experienced in this study, such as exposed northerly faces in Central Otago, may identify a niche for its use. Overall it seems less likely that gland clover will contribute substantially to increase legume content of New Zealand dryland pastures than the other species used.

'Mihi' Persian clover produced over 10 t DM/ha from each sowing date of the year one crops. Of interest was the high yield of the July sown crop which showed a rapid early increase compared with other species. The production of herbage from the autumn sown crops was later than for balansa which is also consistent with lower radiation use efficiency. However, Persian clover would appear more suited to the role of specialist annual legume crop than arrowleaf clover. The higher yields from all sowing dates and potential to regenerate suggests it could be used as a late lactation crop. This means that it may be useful to follow a winter brassica or forage cereal. It would then utilise spring moisture before a mid-summer fallow and establishment of permanent pasture in autumn. The soft seed in 'Mihi' Persian clover meant spring rainfall caused seeds to germinate in the seed heads, but sufficient seed made it to the ground for regeneration crops of 5-10 $\mathrm{t} \mathrm{DM} / \mathrm{ha}$ in year two. The lack of hard seed in this cultivar may be detrimental to ongoing regeneration of seed in following seasons. The variable nature of summer rainfall in most New Zealand dryland regions means there is a high possibility of a "false strike". For cultivars like 'Mihi' this could mean the dropped seed all germinates and dies, leaving no seedbank for establishment in a subsequent autumn flush. This contrasts the dilemma of arrowleaf clover with too much hard seed and indicates a need to match Australian bred annual clover species with local growing conditions. 


\section{Conclusions}

Successful annual species are those that can grow throughout the spring season and mature in early summer, before drought, to maximise yield. This characteristic was found in 'Cefalu' arrowleaf, 'Bolta' balansa and 'Mihi' Persian clovers which all had delayed phenology in response to sowing dates. In contrast, 'Prima' gland clover produced the least growth because it flowered as early as in midwinter and had already matured by mid-spring when temperature and moisture were still favourable for growth. The most versatile of these top flowering species was balansa clover. Its high yield and radiation use efficiency, prolific seed production and ability to regenerate suggests it is worthy of further consideration in more extensive and mixed pastures. The late growth and soft or hard seed issues associated with 'Mihi' Persian and 'Cefalu' arrowleaf clovers may restrict them to specialist crop production for grazing during late lactation. Regardless of sowing dates, rapid canopy expansion did not begin until spring when temperatures began to increase. Thus, crops that were sown late in the winter had a short duration to expand their canopy due to early maturity, therefore limit their biomass productivity. Conversely, autumn sown annual clovers delay their flowering by accumulating vegetative growth. Therefore, it is recommended to sow annual clovers in autumn to maximise dry matter production for winter grazing and to enable crops to set seed before summer drought. It should be noted that autumn sown crops have a longer duration of lag phase, thus making them vulnerable to winter annual weed invasion. Therefore, weed control is important for management of autumn sown crops.

\section{ACKNOWLEDGEMENTS}

We thank Lincoln University and Beef + LambNZ (Pastoral 21 programme) for research funding and Ministry of Higher Education Malaysia for H. Nori's $\mathrm{PhD}$ scholarship.

\section{REFERENCES}

Allinson D.W.; Speer G.S.; Taylor R.W.; Guillard K. 1985. Nutritional characteristics of kura clover (Trifolium ambiguum Bieb.) compared with other forage legumes. Journal of Agricultural Science 104:227-229.

Cooper J.P. 1970. Potential production and energy conversion in temperate and tropical grasses. Herbage Abstracts 40:1-15.

Cosgrove G.P.; Waghorn G.C.; Parsons A.J. 1999. Exploring the nutritional basis of preference and diet selection by sheep. Proceedings of the New Zealand Grassland Association 61:175-180.
Costello T.; Costello A. 2003. Subterranean clover in North Canterbury sheep pastures. Legumes for dryland pastures. Grassland Research and Practice Series 11: 189-192.

Cox J.E. 1978. Soils and agriculture of part Paparua County, Canterbury. D.S.I.R: Wellington, New Zealand. Craig A.D.; Ballard R.A. 2000. Balansa clover(Trifolium michelianum) - a forage legume for temperate pastures. Cahiers Options Méditerranéenes 45: 177 180.

Evans P.M.; Mills A. 2008. Arrowleaf clover: potential for dryland farming systems in New Zealand. Proceedings of the New Zealand Grassland Association 70: 239-243.

Evans P.M.; Snowball R. 1993. Balansa and Persian clover lines outproduce registered cultivars, and subterranean clover and medics, in a $400 \mathrm{~mm}$ annual rainfall zone in Western Australia. pp 53-56 In: Proceedings of the 7th Australian Agronomy Conference, Adelaide.

Gallagher J.N.; Biscoe P.V. 1978. Radiation absorption, growth and yield of cereals. Journal of Agricultural Science, Cambridge 91:47-60.

Hyslop M.G.; Slay M.W.A.; Moffat C.A. 2003 Dry matter accumulation and sheep grazing preference of six winter active annual legumes. Legumes for dryland pastures. Grassland Research and Practice Series 11:117-121.

Kiniry J.R.; Jones C.A.; O'Toole J.C.; Blanchet R.; Cabelguenne M.; Spanel D.A. 1989. Radiation-use efficiency in biomass accumulation prior to grainfilling for five grain-crop species. Field Crops Research 20:51-64.

Knight W.K.; Watson V.H. 1977. Legume variety development and seed needs in the Southeastern United States. In: Proceedings of 23rd Farm Seed Conference, American Seed Trade Association. Eds. Loden, H.D.; Wilkenson, D. Washington D.C

Loi A.; Howieson J.G.; Nutt B.J.; Carr S.J. 2005. A second generation of annual pasture legumes and their potential for inclusion in Mediterranean-type farming systems. Australian Journal of Experimental Agriculture 45: 289-299. DOI: http://dx.doi.org/10.1071/EA03134.

Loomis R.S.; Williams W.A.; Hall A.E. 1971. Agricultural productivity Palo Alto, California, USA, Annual Reviews Inc.

Loss S.P.; Kirby E.J.M.; Siddique K.H.M.; Perry M.W. 1989. Grain growth and development of old and modern Australian wheats. Field Crops Research 21: 131-146. DOI: http://dx.doi.org/10.1016/03784290(89)90049-X.

Mills A.; Lucas R.J.; Moot D.J. 2014. 'MaxClover' grazing experiment: I. Annual yields, botanical composition and growth rates of six dryland pastures over nine years. Grass and Forage Science. DOI: 10.1111/gfs. 12132 . 
Monks D.P.; Moot D.J.; Scott W.R. 2010. Photoperiod affects the flowering time of field-sown balansa clover. Crop \& Pasture Science 61: 639-644.

Monks D.P.; Moot D.J.; Smith M.C.; Lucas R.J. 2008. Grazing management for regeneration of balansa clover in a cocksfoot pasture. Proceedings of the New Zealand Grassland Association 70: 233-238.

Monteith J.L. 1972. Solar radiation and productivity in tropical ecosystems. Journal of Applied Ecology 9: 747-766.

Monteith J.L. 1977. Climate and the efficiency of crop production in Britain. Philosophical Transactions of the Royal Society of London, B 281: 277-294. DOI: 10.1098/rstb.1977.0140.
Nori H. 2013. The development and growth of annual clovers for use in dryland pasture. $\mathrm{PhD}$ thesis. Lincoln University, Canterbury, New Zealand.

Nori H.; Moot D.J.; Monks D.P.; Black A.D.; Lucas R.J. 2014. Reproductive development of four top flowering annual clovers. Crop and Pasture Science 65: 388-399. DOI: http://dx.doi.org/10.1071/ CP13329.

Quinlivan B. 1965. The influence of the growing season and the following dry season on the hardseeedness of subterranean clover in different environments. Australian Journal of Agricultural Research 16: 277 291. DOI: http://dx.doi.org/10.1071/AR9650277.

Sinclair T.R.; Muchow R.C. 1999. Radiation use efficiency. Advances in Agronomy 65: 215-265. 
